\title{
UCLA
}

Mester

Title

Das Secas Fontes

Permalink

https://escholarship.org/uc/item/1966w2b1

Journal

Mester, 3(2)

Author

Williams, Frederick G.

Publication Date

1973

DOI

10.5070/M332013460

Copyright Information

Copyright 1973 by the author(s). All rights reserved unless otherwise indicated. Contact the author(s) for any necessary permissions. Learn more at https://escholarship.org/terms

Peer reviewed 


\section{Das Secas Fontes}

Nao era.

Eu vi que aquela sombra, aquela sombra não era,

uma delas. Eu vi

que era mulher, sim,

sim, muther, sim,

não daquelas.

mas não,

E passando,

vi que mãe não era também,

o filho

não tinha no colo,

no colo,

não tinha no colo

amamentando,

não tinha também.

Quem sera?

- Vagabunda qualquer.

Neste mundo ha tanta

- Maria mendiga- -

há tanta neste mundo,

coitada,

nāo pode mais;

acaba quebrando o peito,

vai quebrar êsse peito:

ela não presta.

não presta já,

Isso foi ha tempo,

muito tempo,

já faz tanto tempo que passou.

Foi ainda esta noite, mas tempos, mundos atras.

Nao a vi,

ninguem a vé,

a encontrarão depois.

Das secas fontes

verte a rubra lágrima sòzinha.

E, perguntei,

por quê?

Compreendi

que é difícil ver desta altura.

Frederick G. Williams 